\title{
PERANAN PADUAN SUARA GEREJA \\ DALAM MEMPERKUKUH SPIRITUALITAS \\ DAN MEMBERI KONSTRIBUSI \\ BAGI IBADAH JEMAAT
}

\begin{abstract}
Rofiani Siafiaan
Intisari

Paduan suara salah satu unsur musik gereja dan merupakan musik vokal, kehadirannya di dalam ibadah bukan hanya semata-mata untuk mempersembahkan lagu puji-pujian. lebih dari itu, paduan suara sesungguhnya mempunyai fungsi primer, yaitu menolong jemaat menyanyi dan menolong jemaat juga untuk memahami fungsi setiap nyanyian pada setiap rumpun tata ibadah.
\end{abstract}

\section{Pendahuluan}

Salah satu unsur musik dalam ibadah gereja pada hari Minggu adalah paduan suara. Yang walaupun keberadaannya tidak dan belum mutlak bagi sebagian gereja, namun tidak dapat disangkal bahwa kehadiran paduan suara dalam peribadatan membawa pengaruh kuat terhadap jemaat dan kelangsungan ibadah itu sendiri. Hal ini tampak dari respons jemaat terhadap pelayanan paduan suara dan juga gairah dari anggota paduan suara untuk memenuhi pelayanan sekaligus ibadahnya.

Gereja sebagai wadah dan tujuan paduan suara "menyalurkan" aktivitasnya, sesungguhnya dapat mengoptimalkan pelayanan paduan suara dalam tata ibadahnya. Selama ini realitas yang terjadi, bahwa paduan suara masih dianggap hanya sebatas pelengkap atau aksesoris ibadah. Yang sebenarnya diharapkan ialah keterbukaan gereja untuk menjadikan paduan suara sebagai bagian dari tata ibadah atau liturgi; artinya pada bagianbagian tertentu dari rangkaian ibadah gereja, ada bagian di mana paduan suara diberi tanggung jawab.

Dalam hubungan dengan judul di atas, maka yang menjadi pertanyaan adalah, sejauh mana paduan suara berperan dalam memperkukuh spiritualitas anggotanya secara khusus dan jemaat pada umumnya? Dan apa kontribusi paduan suara bagi ibadah secara menyeluruh?

\section{Pengertian Paduan Suara}

Pertama-tama yang perlu diketahui adalah pengertian paduan suara secara benar, sebab sering kali jemaat ataupun masyarakat mengartikan paduan suara hanya sekelompok orang yang senang bernyanyi dan suka menyanyi kapan dan di mana dia suka, jadi hanya bersifat temporer. Tidak semua pendapat di atas salah, tetapi untuk lebih tepatnya, mari kita lihat apa sebenarnya yang disebut paduan suara.

Secara umum, pengertian paduan suara ialah, menyanyi bersama yang terdiri atas suara sopran, alto, tenor dan baritone; atau biasa juga disebut kor atau choir di kalangan gereja. Selain itu, ada juga yang mengartikan paduan suara sebagai kesatuan sejumlah penyanyi dari beberapa jenis suara yang berbeda, yang berupaya memadukan suaranya di bawah pimpinan seorang dirigen.

Berdasarkan pengamatan dan pangalaman penulis selama berkecimpung 
dalam kegiatan paduan suara gereja, dapat diartiakan: paduan suara adalah satu kelompok orang yang terdiri atas pria dan wanita dengan golongan suara yang berbeda yang disebut sopran, alto, tenor dan bas (SAT B). Memiliki kemauan dan ketekunan (motivasi) yang benar untuk mencapai tujuan yang sama dalam menjalankan tugas panggilannya memberitakan firman Tuhan lewat puji-pujian yang dipersiapkan secara terlatih dan terampil di bawah pimpinan pelatih atau dirigen; memiliki program dan pelayanannya berlangsung terus-menerus.

\section{Paduan Suara Menurut Masanya}

Untuk memahami paduan suara, tidak bisa tidak, kita harus melihat sejarah asal mula adanya paduan suara. Tiga masa yang mempengaruhi "kebiasaan" adanya musik paduan suara dalam peribadahan umat hingga masa kini, yaitu:

\section{Masa Perjanjian Lama}

Sejak masa Alkitab sampai pada zaman sekarang, paduan suara sudah tidak asing lagi bagi jemaat atau umat. Pada masa Perjanjian Lama, paduan suara sangat berperan dalam kegiatan peribadatan umat Israel, ini dapat dibuktikan dari "Paduan Suara Tebernakel" yang diorganisasi langsung oleh Daud (I Taw. 15:11-22; 16:4,5; 25:1-7). Untuk penahbisan Bait Allah, paduan suara terdiri atas 4000 penyanyi diorganisasi oleh Raja Salomo (I Taw. 23:5,27-32; II Taw.5:11-14). Setelah masa pembuangan, umat Israel membangun kembali Bait TUHAN di Yerusalem, ada paduan suara yang diorganisasi oleh Zerubabel terdiri atas 200 orang pria dan wanita (Ezra 2:41,65,70; 3:10-13); sedang Nehemia pada masanya pun mengorganisasi paduan suara untuk penahbisan tembok Yerusalem (Neh. 7:1; 11:22,23; 12:27-30; 13:5,10). Tidak heran jika Yoshepus, seorang sejarawan Yahudi yang hidup pada abad pertama mengatakan, "Untuk melayani kebaktian di Bait Allah, lebih kurang 200.000 umat Israel menjadi anggota paduan suara yang terlatih dan terorganisasi dengan baik" ${ }^{\prime 1}$, dan Strabo, seorang ahli ilmu bumi Yunani menilai, "Para penyanyi paduan suara yang melayani di Bait Allah sebagai yang paling merdu suaranya di seluruh dunia". ${ }^{2}$

\section{Masa Perjanjian Baru}

Dalam Perjanjian Baru, secara rinci tidak disebut paduan suara. Yang dapat dicatat adalah nyanyian-nyanyian dan puji-pujian sebagai suatu aktivitas yang lazim dalam ibadah jemaat (Rom. 15:9; Ef. 5:19; Yak. 5:13). Selain itu, beberapa nyanyian yang sudah dikenal adalah Magnificat atau nyanyian pujian Maria (Luk. 1:46-55); Benedictus atau nyanyian pujian Zakharia (Luk. 1:68-79); dan Hymn yang dinyanyikan Simeon (Luk. 2:29-32). Rasul Paulus kepada jemaat di Kolose menyebutkan tiga macam nyanyian yang harus dipakai jemaat untuk bersyukur dan menyikapi hidup dalam persekutuan selaku orang-orang yang beriman, (Kol. 3:16). Yesus juga dalam pelayanan-Nya menaikkan puji-pujian bersama dengan para murid; barangkali bersama para pengikutnya juga? (Mar. 14:26). Paulus dan Silas dengan nyanyian bersaksi tentang kebenaran Tuhan dalam Yesus Kristus, membuat kepala penjara bertobat dan mengakui Yesus adalah Juruselamat (Kis. 16:25).

Meskipun dari nyanyian dan pujipujian yang sudah disebutkan tadi tampaknya hanya dinyanyikan secara perseorangan atau kelompok kecil saja, dan itu merupakan kesaksian pribadi, tetapi kata-kata dan bentuk nyanyian berbeda 
antara satu dengan lainnya. Menurut Abineno, "Ada nyanyian berupa aklamasi (homologia, pengakuan), berupa proklamasi (kerugma, pekabaran), doa-doa, dan doxologi", ${ }^{3}$ namun satu hal yang penting adalah mereka telah meneruskan kesukaan yang mereka alami kepada orang lain. Dengan menyanyi, jemaat bersama-sama memuji dan bersaksi atas kebesaran Tuhan Allah dengan segala karya agung yang telah dilakukan-Nya kepada hambahamba-Nya dan seluruh umat-Nya.

\section{Masa Gereja Mula-mula}

Sesudah bait suci dihancurkan pada tahun $70 \mathrm{AD}$, hal positif yang dapat dicatat bahwa kebaktian tetap berjalan walaupun secara sembunyi-sembunyi karena masa itu terdapat penganiayaan bagi orang-orang Kristen. Selama masa sulit ini, kekuatan nasionalis Yahudi dihancurkan bangsa Romawi, akibatnya hubungan upacaraupacara Yahudi dengan upacara Kristen terputus. Kebangkitan musik dimulai pada abad-abad pertama. Saat ini para pekerja gereja bertanggung jawab penuh atas ibadah, sehingga mereka mengatur dan menentukan liturgi sendiri dan musik mulai diikutsertakan. Nyanyian yang digunakan masih Mazmur Daud dan nyanyian tua yang dibawakan paduan suara yang kelak kemudian menjadi permulaan spiritual song.

Musik berkembang terus seiring perubahan dan perkembangan zaman. Sampai pada masa abad pertengahan, kebangkitan musik tampak lebih maju, tetapi untuk musik gereja jemaat hanya menjadi pendengar. Yang bertugas dalam ibadah mulai dari membaca Alkitab, menyanyi untuk merespons firman dan apalagi paduan suara, semua dilakukan oleh kaum biarawan. Aliran musik Gregorian yang tadinya hanya "dikonsumsi" oleh kalangan biarawan, mulai dikenal secara luas sampai akhirnya berkembang menjadi dasar yang kuat untuk musik paduan suara gereja setelah masa reformasi. Musik paduan suara dengan musisi-musisinya mulai bermunculan, mulai dari Gregorian sampai Palestina, musisi gereja berkembang terus seiring perkembangan musik profan yang sedikit banyak berpengaruh juga terhadap musik gereja.

\section{Masa Kini}

Untuk masa kini, kebanyakan paduan suara gereja dibentuk oleh pihak gereja lewat departemen musik atau komisi musik. Biasanya paduan suara ini terdiri atas kelompok paduan suara dewasa campuran pria-wanita; paduan suara pemuda; kaum ibu; dan kaum bapak. Ada juga paduan suara anak dan teruna, apabila ada tenaga yang siap menangani kelompok ini. Tetapi di luar dari itu, ada juga yang dibentuk berdasarkan wilayah atau sektor masing-masing yang "independen" pun banyak seperti paduan suara kerukunan keluarga, mahasiswa dan beragam lagi kelompok-kelompok paduan suara yang pelayanannya tetap di gereja, meskipun untuk hal-hal yang insidentil mereka mengadakan pelayanan di luar. Selama paduan suara masih "patuh" dalam koridor yang diatur oleh gereja, tidak ada masalah. Yang "repot" adalah jika ada paduan suara yang menjadikan gereja sebagai gedung konser dan merasa punya hak untuk melayani menurut keinginan sendiri.

\section{Paduan Suara Ssebagai Suatu Aktivitas Pelayanan}

Paduan suara tidak sama dengan nyanyian jemaat, tetapi merupakan bentuk lain dari musik gereja; hal ini diungkapkan oleh Yoseph N. Asthon dalam Music in Worship "dari semua musik gereja, musik 
paduan suara memiliki nilai paling tinggi, diorganisasi secara baik, membentuk berbagai ragam perasaan, dan menjadi dasar yang paling kuat untuk mempelajari musik gereja." 4

Di dalam ibadah, paduan suara mempunyai "posisi" yang cukup strategis. Untuk menjalankan visi dan misinya sebagai suatu kegiatan pelayanan yang berhasil dan sungguh-sungguh bagi gereja, kelompok paduan suara harus memiliki dasar yang kukuh sebagai komponen penggerak, yaitu:

\section{Kepentingan Paduan Suara}

Pertama, Untuk Tuhan. Melalui pelayanan paduan suara, kesaksian tentang kebenaran Allah sebagai Firman yang hidup menjadi nyata. Setiap orang dilayakkan menjadi pekerja-Nya (2 Tim. 2:15).

Kedua, Untuk Jemaat. Melalui pelayanan paduan suara jemaat memperoleh pengajaran tentang hal-hal yang mendasar dari iman. Juga dapat menarik orang-orang untuk mengikuti kegiatan gereja serta kesempatan untuk bertanggung jawab dalam pelayanan.

Ketigu, Untuk Anggota. Melalui paduan suara akan terjalin persekutuan yang lebih erat, akrab dan ada rasa untuk saling memperhatikan, saling melengkapi, saling mendukung, karena keanggotannya yang universal: ibarat sebuah gereja lokal yang digambarkan oleh Michael Griffiths dalam Gereja dan Panggilan Dewasa Ini, "Kelompok paduan suara senantiasa terbuka untuk siapa saja yang ingin datang atau masuk menjadi anggota; tidak mengenal usia, jenis kelamin, suku, warna kebangsaan, kelas sosial dan kemampuan intelektual (Gal. 3:28; Yak. 2:1-4), mereka yang berbeda pendapat tidak harus dikucilkan (Rom. 14:1); atau bahkan mereka yang tidak percaya (1 Kor. 14:24-25). ${ }^{5}$
Perangkat Paduan Suara

Pertama, Anggota. Seperti sudah disebutkan sebelumnya, paduan suara adalah kumpulan orang-orang yang bersepakat untuk bernyanyi bersama-sama secara terlatih dan terpimpin; artinya ada sejumlah orang yang terlibat di dalam sebagai anggota. Siapakah mereka? Dari aspek rohani, mereka anggota gereja yang aktif, terpanggil dan terbeban untuk meningkatkan pelayanan; sudah dewasa rohani dalam arti sudah memahami jelas tujuan dan arah kegiatan pelayan paduan suara hanya untuk kemuliaan Allah dan bukan hal yang lain. Dari aspek pribadi, harus seorang yang bertanggung jawab, setia, siap bekerja sama secara tim, mendukung program paduan suara secara menyeluruh. Satu pengalaman bersama almarhum E. L. Pohan, seorang pakar dan komponis musik gereja berkata, "Buat dirimu penting, seolah-olah tanpa kehadiranmu paduan suara tidak lengkap dan tak akan sempurna bernyanyi" katakata ini selalu diulang-ulang ketika mengingatkan seluruh anggota yang akan melayani pada hari Minggu. Artinya di sini ialah, supaya anggota memahami harga kehadiran dan tanggung jawab setiap pelayanan. Harus ada motivasi, motivasi yang benar menjadi tenaga pendorong serta kekuatan dalam proses belajar (motivation is a power). Pelayanan bukan untuk menyenangkan hati manusia, tetapi hati Tuhan (1 Tes. 2:4). Dari aspek musik, seorang anggota sebaiknya mempunyai kemampuan vokal, kualitas nada konstan, dapat bernyanyi pada tinggi rendah nada, mandiri dalam arti tidak mudah terpengaruh dengan suara lain. Memiliki pendengaran yang baik. Seorang yang bersuara sederhana, tetapi pendengaran baik harus lebih diutamakan daripada yang memberi kesan suaranya baik, tetapi telinganya kurang. Juga memiliki rasa seni 
terhadap birama dan irama serta unsurunsur musik lainnya. Para pakar musik mencatat, faktor keturunan sangat dominan mendukung bakat atau telenta anggota; biasanya yang tidak berbakat tidak dapat dipaksa-paksa, tetapi ketekunan tentu saja dapat meningkatkan bakat.

Kedua, Konduktor atau Dirigen.

Konduktor adalah pemersatu dan jiwa dari paduan suara; ia memiliki tugas dan tanggung jawab penuh atas kehidupan paduan suara. Dari aspek rohani, ia seorang yang penuh kasih, sangat dekat kepada Tuhan, terpanggil untuk melayani dan menjadikan Firman sebagai dasar dari setiap nyanyian yang diajarkan. Dari aspek pribadi, kepribadiannya senantiasa menunjukan sikap positif, baik tindakan maupun perkataan. Seorang konduktor harus memiliki komitmen dalam melayani; seperti kata Ray Robinson dan Allen Winold dalam The Choral Experience, "Konduktor itu berhubungan dengan orang banyak, di mana orang itu sendiri yang menjadi alat atau instrumen; konduktor berhubungan dengan anggota yang tingkat kemampuan pengungkapan musikalnya belum tentu sama; ada yang sama sekali belum memadai atau bahkan belum 'ada apa-apanya'". ${ }^{6}$ Kemudian penampilan lahiriah seorang konduktor sangat ber-pengaruh terhadap paduan suara. Sikap tubuh (postur), kerapian, ketenangan dan kesabaran menjadi alat pendukung bagi seorang konduktor untuk diterima di kalangan anggota paduan suara; di samping kemampuan mengajar dalam posisi sebagai guru, sebagai pelatih, sebagai pendidik dan pembina sekaligus menjadi teman bagi seluruh anggota, tanpa harus menanggalkan kedisiplinan dan ketegasan sebagai satu sikap yang wajar selaku seorang pemimpin.

Ketiga, Pengurus. Kepengurusan paduan suara dibentuk dan dipilih sesuai dengan potensinya, terdiri atas ketua, sekertaris, bendahara, plus seksi-seksi. Yang penting diperhatikan adalah kedudukan seorang konduktor hanya sebagai pelatih, "guru" dalam arti teknik memimpin dan melatih serta mempersiapkan pelayanan paduan suara. "Meskipun pendapatnya masih diperhitungkan, tetapi kelangsungan paduan suara secara organisasi diatur oleh pengurus dan seksi koor serta seksi ibadah sangat berperan dalam kelancaran "hidup" paduan suara."

\section{Musikalitas Konduktor}

Pertama, Kemampuan teknik conducting. Kemampuan yang dituntut, baik secara teori maupun praktek, secara fisik dan rasa seni. "The skill conducting can be learned, but not the art", artinya aba-aba, gerakan tangan tubuh atau pun mimik wajah dapat dilatih dan ditekuni, tetapi lebih penting lagi adalah perasaan seni; sebab dengan jiwa seni seorang konduktor akan mampu mengendalikan emosi, intelek dan hati para penyanyi dan diri konduktor sendiri.

Kedua, Kemampuan teknik vokal. Keindahan suara tak dapat dituntut dari seorang konduktor, tetapi penguasaan teknik bernyanyi dengan berbagai ekspresi harus, karena tugasnya berkenaan dengan pembentukan suara, penempatan suara sesuai karakter, memberi contoh suara yang pas dan tepat.

Ketiga, Kemampuan teknik pengungkapan. Di sini dituntut kemampuan konduktor untuk memahami nyanyian, baik dari melodi, harmoni maupun komposisi, terutama dari segi isi, bentuk dan karakter lagu. Interprestasi yang benar atas sebuah nyanyian bukan saja akan menghasilkan penyajian yang baik dan "enak" untuk dinikmati, tetapi juga akan menciptakan nuansa musik yang indah, yang menimbulkan kekuatan, kelegaan, 
dan pemulihan dalam jiwa pendengar serta para penyanyi. Don Campbell, secrang musisi dan educator terkemuka di duniâa dalam hubungan antara musik dan penyembahan, dalam bukunya yang berjudul Efek Mozart, menekankan, "Penjiwaan musik sebagai metode terapi yang handal terhadap pasien yang menjalani pengobatan lewat musik."

\section{Peranan yang Memperkukuh Spiritualitas dan Menjadi Konstribusi Bagi Ibadah Jemaat}

Sebagaimana kita ketahui fungsi musik gereja adalah dalam ibadah. Paduan suara yang menjadi salah satu unsur musik gereja dan merupakan musik vokal, kehadirannya di dalam ibadah bukan hanya semata-mata untuk mempersembahkan lagu puji-pujian. Lebih dari itu, paduan suara sesungguhnya mempunyai fungsi primer, yaitu menolong jemaat menyanyi dan menolong jemaat juga untuk memahami fungsi setiap nyanyian pada setiap rumpun tata ibadah.

Pemahaman yang kurang akan fungsi nyanyian dalam ibadah hari Minggu, sering kali menimbulkan kejanggalan-kejanggalan yang sebenarnya dapat dihindari jika ada komunikasi dan kerja sama di antara pemimpin ibadah dengan pemusik gereja atau dengan kelompok paduan suara yang bertugas. Misalnya, nyanyain jemaat dinyanyikan oleh paduan suara sebagai persembahan puji-pujian. Ketika paduan suara membawakan lagu tersebut, jemaat seperti mendengar satu lagu baru yang indah dan bermakna. Mengapa? Karena paduan suara menyanyi dengan melodi disertai harmoni lengkap, penjiwaan lagu selaras dengan pembawaan yang "profesional" dan ketika lagu yang sama (kebetulan saja!) dinyanyikan sebagai nyanyian jemaat, cenderung "loyo" dan 'erasa biasa-biasa saja. Kekonyolan lain yang bisa terjadi adalah paduan suara menyanyikan "Yesus Bangkit" padahal kalender gereja adalah minggu advent, bahkan sering kali paduan suara tidak memperhatikan lagu yang dibawakan, sesuai tidak dengan doktrin gereja? Atau lagu-lagu jemaat dari minggu ke minggu itu-itu terus, sehingga nyanyian yang mestinya hanya cocok untuk persembahan, dinyanyikan sebagai lagu pembukaan ibadah, demikian sebaliknya. Untuk hal inilah, pengetahuan dasar teologi dan liturgi gereja harus dimiliki seorang pemimpin paduan suara atau konduktor, sebab seorang pemimpin musik adalah juga mitra dari hamba Tuhan atau Pendeta.

Peranan paduan suara yang lain dapat dilihat pada saat mereka melayani di dalam gereja. Mereka berada bersamasama jemaat, artinya mereka memberi respons yang "wajar" dan "layak" dalam setiap rumpun ibadah. Tidak merasa berbeda dari pada jemaat dan tidak merasa lebih tinggi dari jemaat karena mempunyai kesempatan untuk "tampil" sendiri. Sebaliknya ketika jemaat menyanyi, mereka pun menyanyi. Mereka menjadi "motor" bagi jemaat untuk menyanyikan lagu-lagu baru dan menjadi penuntun yang benar untuk tematik ibadah yang mungkin masih baru bagi jemaat. Kemudian ketika mereka menyanyi atau mempersembahkan pujipujian, saat itu sama dengan mereka sedang memperdengarkan firman Tuhan. Kadang kala jemaat kurang memperhatikan khotbah atau firman Tuhan yang disampaikan pendeta, tetapi mendengar paduan suara menyanyi, mereka tersentak dan sadar oleh kata-kata nyanyian yang dibawakan dengan jelas dan sangat dihayati oleh para penyanyi. E. L. Pohan mengatakan, "Menyanyi adalah ber- 
khotbah". Yang dimaksud di sini ialah, paduan suara memiliki tugas supaya misi nyanyian boleh sampai kepada pendengar dan menjadi kesaksian yang hidup di tengah-tengah jemaat.

Dengan demikian, melalui nyanyian dan "penampilannya" paduan suara telah ikut membina dan memperkukuh spiritualitas jemaat dan anggota-anggota paduan suara sendiri. Peran ini dengan sendirinya dapat terpenuhi apabila dalam proses persiapan pelayanan, konduktor sudah memberi pemahaman yang benar atas setiap nyanyaian dan kehendak apa yang mau dicapai lewat nyanyaian.

Selain dari peranan paduan suara dan fungsi nyanyian yang dinyanyikan oleh paduan suara, kita melihat bahwa seorang anggota paduan suara yang sudah terbina baik dan diarahkan dengan metode pendidikan musik yang baik dan bermutu, kelak akan meningkatkan kemampuan menyanyinya dengan teknik vokal yang tinggi. Inilah kontribusi paduan suara bagi ibadah jemaat. Musisi-musisi paduan suara yang telah berhasil, kelak akan menjadi sumber daya yang potensial untuk melayani sebagai penyanyi Solo, Cantoria atau Singers, Vokal Grup dan menjadi kader baru untuk membina paduan suara dan nyanyian jemaat.

Sedikit tentang nyanyian, sekarang ini banyak bermunculan koor-koor pendek dan nyanyian rohani baru yang sangat digemari jemaat, terutama kaum muda dan remaja. Sebetulnya tidak salah, hanya saja perlu diwaspadai teologi dan doktrin yang terkandung di dalam kata-katanya, apakah Alkitabiah dan misinya benar untuk memberitakan karya Allah dalam Yesus Kristus? Dari pengamatan penulis, secara umum banyak yang isinya dangkal dan bahasanya tidak tepat sehingga pengertiannya menjadi kabur. Sangat disayangkan apabila gereja malas dan enggan untuk menyanyikan lagu-lagu dari buku nyanyian yang ada di gereja hanya karena tidak tahu (karena tidak mau dan malas mempelajarinya) atau alasan klasik, sudah kuno? Hal ini menjadi tugas dan tanggung jawab paduan suara dan pihak gereja yang berkompoten untuk itu. Kelompok paduan suara jangan hanya mempelajari lagu-lagu paduan suara yang tingkat kesulitannya bisa membuat stress, sementara nyanyaian jemaat diabaikan. Perlu kerja sama yang baik antara gereja dengan pemimpin paduan suara, bila tidak maka nyanyian-nyanyian yang nilai musik dan kata-katanya baik di buku nyanyian jemaat akan jadi apa? Rasul Paulus mengatakan jangan lalai menyanyikan mazmur, puji-pujian, dan nyanyian rohani (Kol. 3:16). Sebaliknya sebelum latihan dimulai, ibadah singkat dibuka dengan nyanyian jemaat yang dipersiapkan untuk ibadah hari Minggu, dengan begitu paduan suara telah menolong jemaat untuk menyanyi secara benar dan tepat.

\section{Penutup}

Berdasarkan uraian di atas jelas sudah apa dan bagaimana sesungguhnya keberadaan dan kehadiran suatu kelompok paduan suara di gereja. Tidak secara kebetulan mereka ada, karena di dalamnya ada proses yang menyangkut perencanaan, persiapan, pembinaan, pelatihan dan pelayanan. Memang bisa dikatakan "sumber insani" berasal dari dan oleh mereka yang menjadi anggota paduan suara, tetapi mereka tetap merupakan bagian dari gereja yang tentu saja masih tetap membutuhkan kepedulian pimpinan gereja.

Untuk meningkatkan pelayanan ibadah gereja, paduan suara sepatutnya dilibatkan secara langsung. Jika tematik ibadah sudah "utuh" dan "baku" serta tak dapat lagi "diganggu gugat", yang paling sederhana adalah melalui nyanyian jemaat. 
Dalam hal ini nyanyian jemaat dibawakan dengan cara antivonal (antar kelompok), responsorial (bersahut-sahutan), dan alternatium (bergantian antar jenis), antara jemaat, penyanyi solo, vocal group dan paduan suara. Masing-masing menyanyi pada bait atau bagian yang sudah diatur atau ditentukan oleh pemimpin pujian dalam ibadah. Dengan cara ini pula seluruh bait utuh dinyanyikan; di samping ada nuansa baru dalam nyanyian, jemaat pun dibangkitkan semangatnya serta gairahnya dalam memuji Tuhan.

Menyanyikan puji-pujian kepada Tuhan berbeda dengan menyanyikan lagulagu profan. Menyanyikan puji-pujian tidak hanya dengan mulut dan wajah yang menyanyi, tetapi hati dan jiwa harus menyatu dengan lagu. Rasul Paulus dalam 1 Kor. 14:15 mengatakan, "Aku akan menyanyi dan memuji dengan rohku, tetapi aku akan menyanyi dan memuji juga dengan akal budiku." Dengan nyanyian iman orang percaya akan dikuatkan dan semakin bertumbuh di dalam kasih Kristus. Dengan nyanyian banyak jiwa yang datang bertelut kepada Tuhan dan mengaku Yesus Kristus adalah Juruselamat. Dengan paduan suara sebagai alat, maka nyanyiannyanyian indah akan tetap berkumandang di hati jemaat Tuhan.

\section{(Endnotes)}

${ }^{1}$ Jurusan Musik Gerejawi STT Jaffray, Perkembangan Musik Gerejawi dari Masa ke Masa, hal.

${ }^{2}$ Ibid. hal. 3

${ }^{3}$ Abineno, J.L.Ch, Unsur-Unsur Liturgia, hal. 109118

${ }^{4}$ Ashton, Joseph N., Music in Church, hal. 122

5 Griffiths Michael., Gereja dan Panggilannya Dewasa Ini, hal. 203.

6 Ray Robinson and Allen Winold., The Choral Experience, hal. 193.

7 Ibid. hal. 193

${ }^{8}$ Campbell, Don., Efek Mozart, hal. 149

\section{Kepustakaan}

Abineno, J.L.Ch, Unsur-Unsur Liturgia.

Ashton, Joseph N., Music in Church.

Campell, Don., Efek Mozart.

Cermat, H.L., Kidung dan Kecapi, Musik dalam Alkitab.

Griffiths Michael., Gereja dan Panggilannya Dewasa Ini.

McNeill, Rhoderick., Sejarah Musik 1,2.

Ray Robinson and Allen Winold., The Choral Experiance.

STT Jaffray Ujung Pandang, Jurusan Musik Gerejawi., Perkembangan Musik Gerejawi dari Masa ke Masa. 